\title{
MISSIO DEI AND COMPASSIO DEI: MINORITY CHRISTIANS EXPERIENCING GOD'S ACTS IN THE FACE OF HOSTILITY ${ }^{1}$
}

\author{
Christof Sauer ${ }^{2}$ \\ Department of Practical Theology \\ University of South Africa
}

\begin{abstract}
This article examines what we can learn about being a 'missional church'from reading the book of Acts with minority Christians experiencing God's acts in the face of hostility. Romanian theologian Josef Ton discovers three lessons on suffering and martyrdom in the book of Acts: understanding the sovereignty of God, regarding suffering for Christ as a privilege and an honour, and trusting the leading and empowering of the Holy Spirit.
\end{abstract}

Key Words: Suffering for Christ, Theology of Martyrdom, Acts, Missio Dei

\section{Introduction}

What can we learn from the book of Acts about being a missional church? And more specifically: what can we learn about the acts of the living God? Let me plunge right into my subject with a quote:

The Book of Acts emphasizes the necessity of a clear understanding on the part of the messengers of the gospel of what lies in store for them; they need to know that they will almost certainly encounter extreme violence and even death if they obey Christ and witness to others about Him. For instance, the same warning that Jesus had given to the apostles during their training was given to Saul immediately after Ananias announced to him that he had been chosen to bear the name of Jesus before the Gentiles, kings, and the children of Israel: "For I will show him how much he must suffer for my name's sake" (Acts 9:16) (Ton 1997:113).

Who is it that draws such lessons from the book of Acts about being a messenger of the gospel? It is Josef Ton, a theologian from Romania who studied theology at Oxford in the early 70s. He was led into the study of martyrdom as a result of the circumstances of his life: "As I was making plans to return to Romania, I received different warnings that after my return there I might be arrested, imprisoned or even killed. I knew that God wanted me back in my own country, and I was determined to obey Him, whatever the cost. Yet I wanted to understand exactly what my Heavenly Father's purpose could be in sending me to a place where I would most likely be killed ... [The] astonishing biblical principle that God always conquers through people who will preach the gospel and then die for it helped

\footnotetext{
A contribution to the study group on "Acts of the living God" at the conference: "What can we learn from the book of Acts about being a Missional Church?", 18-20 May 2009, Stellenbosch, South Africa.

2 Dr Christof Sauer (*1963) ) is a co-researcher of the Research Programme on Religion, Health and Wellbeing in Southern Africa - Practical Theological Perspectives, Department of Practical Theology, University of South Africa. He is also the co-director of the International Institute for Religious Freedom of the World Evangelical Alliance <www.iirf.eu $>$, and a temporary lecturer in missiology at the Theological Faculty in Stellenbosch. E-mail: Christof@iirf.eu.
} 
me immeasurably to be able to return to Romania. It gave me the solid rationale I needed for the dangerous return home. Buttressed with this teaching, I preached, lectured, and wrote for nearly a decade, ready to be martyred for what I was doing, yet knowing that death would be my supreme weapon of conquest and my road to the highest glory in heaven" (:xi-xii). Ton faced various tribulations under the Communist regime, the police searched and ransacked their family home, he and his wife were arrested and interrogated, and eventually in 1981 they were exiled from Romania and subsequently settled in America. He carried on his research on the issue of martyrdom which finally culminated in a doctorate on "Suffering, martyrdom, and rewards in heaven" which was published by the University Press of America in 1997. This work contains a chapter on "Suffering and martyrdom in the book of Acts" from which I will mainly draw in this article.

His is the most coherent and original treatment of Acts which I have found in surveying contemporary works on suffering, persecution and martyrdom for Christ by evangelical Christians in minority situations. ${ }^{3}$

The topic of my article is much narrower than "mission and martyrdom in the book of Acts". Rather than focusing on the persecutors or the persecution and its gory details with which Western Christians often become preoccupied because they are so unfamiliar with these things, I want to focus on God's acts when reading the book of Acts. I want to focus on the compassio dei that goes along with the missio dei, God's suffering in and with those he has sent on his mission and his acts as a living God, safeguarding his church in the midst of hostility and persecution and enabling it to continue its mission through suffering and martyrdom.

My starting point when reading Acts from the perspective of 'persecuted gospel sharing Christians' is Acts 1,8: Christians are empowered by the Holy Spirit of God to bear witness to Jesus by preaching the gospel to the ends of the earth. Ton sees this as the programme and outline of the Book of Acts.

The passion to proclaim to the whole world what one has discovered in Jesus Christ is the first of many apostolic traits depicted in the book of Acts that became a model for Christians throughout the ages. However, another apostolic trait that has not been universally followed, is the willingness to suffer for this witness. Ton asks: "Why were the disciples ready to suffer and to die for the name of Jesus and for His gospel?" He finds three answers in examining how Luke "selected and presented his material in order to convey the rationale for suffering and martyrdom for the sake of Christ" (:114). I will use these to highlight three lessons we can learn from the book of Acts about being a missional church.

\section{Understanding the Sovereignty of God}

"The first element that was an essential part of the mind of the disciples was their clear understanding of the sovereignty of God. This is the key to a disciple's faithfulness in times of persecution." This lesson is drawn from the prayer of the believers after John and Peter were interrogated and threatened for preaching and healing in the name of Jesus (Acts 4:24-30).

Ton (:114-116) highlights that "throughout their prayer, the disciples emphasized the fact that God was in absolute control over the events of history". God is addressed as despota, absolute ruler (4:24), a name almost unique to the New Testament. They begin by

This is part of a larger research project on non-Western evangelical theologies of persecution and martyrdom. While I have also consulted Western authors on a theology of persecution in Luke-Acts, such as Penner and Cunningham, space does not permit to engage with them. 
quoting the second Psalm, which portrays God mocking and laughing at his enemies, as they plot against his son, the Messiah. With this picture in mind, they interpret what had just happened to Jesus. Ultimately what the enemies could do "would surely turn out to be simply a part of the fulfilment of [God's] ultimate plan, which is the triumph of the Messiah and of His people". Therefore their prayer was neither a fearful prayer begging God for protection, nor an angry prayer railing against evil aggressors. According to Ton there "were only two things for which the church could rightly pray": for boldness to continue preaching the gospel and for signs and wonders to accompany their preaching, so that the name of Jesus may be lifted up. Ton concludes: "a deep understanding of the sovereignty of God is so vitally important. God's children must know that He is in absolute command, that He works even through His enemies, and that He is consistently accomplishing His purposes even through adversities."

\section{Regarding Suffering for Christ as a Privilege and an Honour}

The second element in the thinking of the disciples that kept them going strong through constant adversities was their view of suffering as a privilege and honour.

Ton explains (:116-117): The humiliating and savage beating which Peter and John were submitted to like criminals in front of the country's top leaders was meant to dishonour them. But they received it as a very special treatment (5:41). "One had to be found 'worthy' of it! Suffering was not for everybody. Since it was only given to a select number of people chosen by God, being among the people especially honoured by God to suffer for His Name was a reason for great rejoicing indeed!" Therefore the apostles did not return complaining and soliciting pity, but reported the joyful news, that they had been counted worthy by their Lord to suffer indignity for his name.

Ton sees the same attitude illustrated later on when Paul and Silas are found in a Philippian jail, beaten and their feet placed in the stocks, singing hymns to God, "giving a concert to all the prisoners around them" (16:22-25). While the concept that suffering for Christ is a privilege and honour "has been central to the thinking of suffering Christians over the centuries", Ton also places it in perspective by reminding that "a certain amount of suffering is the lot of all Christians" and that "the eyes of Christians should be fixed upon the final goal of the journey: their entrance into the kingdom of God." He draws this lesson from Paul, who shortly after almost being stoned to death in Lystra, returns to the believers there, encouraging them to continue in the faith, saying 'Through many tribulations we must enter the kingdom of God' (14:22).

\section{Trusting the Leading and Empowering of the Holy Spirit}

According to Ton, "the third component constituting the mind of the disciples was their perception of the glory of martyrdom." And indeed Luke gives a very elaborate presentation of the first Christian martyrdom, namely that of Stephen, and Ton (117-123) devotes half of his chapter on Acts to it. The most important element in the martyrdom of Stephen is identified by Ton as the leading and empowering role of the Holy Spirit. I therefore use this point as a heading.

Ton notes that Luke's account on Stephen's death follows the pattern of the trial and death of Jesus (deeds of power, accusation of speaking against Temple, Son of Man at the right hand of God, prayer for forgiveness, committing of spirit to God). Luke had the express intention of presenting Stephen as a fully trained pupil of Jesus, who is like his teacher (Lk 6:40).

Ton highlights four features of the martyrdom of Stephen. The first was Stephen's 
courage to tell his audience that their faith was misplaced and that the Son of Man, seated at the right hand of God, was the true object of saving faith (Acts 7:51-52). The second important feature in Stephen's martyrdom is his vision of heaven. Ton interprets Luke 9:27 as a promise of Jesus to his disciples, "that before they will die for his sake, they will receive a vision of [Gods'] glorious kingdom." The unusual reference to the Son of Man standing at the right hand of God is explained as legal terminology of the Old Testament, where the judge is described as sitting, and the vindicating witness is described as standing to his right side. ${ }^{4}$ The purpose of the vision of heaven given to a person on the threshold of martyrdom is twofold: The first purpose is to be a witness for the people who are standing by, watching the execution. The second purpose is for the martyr himself. It has a transforming impact upon that person. The glory is so great that the tortures are no longer worthy of being taken into consideration after one has seen it. The third feature in Stephens martyrdom highlighted by Ton is Stephen's prayer for the forgiveness of his enemies and killers, thus not only preaching the love of God manifested in His Son Jesus Christ, but also living it out in his own suffering. I would regard all three features of the martyrdom of Stephen mentioned above, the courage, the vision of heaven and the willingness to forgive, as a work of the Holy Spirit.

The feature Ton considers most important in the martyrdom of Stephen is - as noted before - the leading and empowering of the Holy Spirit. Stephen is presented as a person full of the Holy Spirit, performing wonders and signs in the power of the Holy Spirit, and being filled with the Holy Spirit at the climax of his address to the Sanhedrin (Acts 6:5; 6:8; 7:55). Ton comments: "The prominence of the Holy Spirit in the action of witnessing to Christ and His gospel is visible in the entire Book of Acts to such an extent that the book has been commonly surnamed 'The Acts of the Holy Spirit.' ... the power of the Holy Spirit was manifested in the boldness of the Apostle Peter (Acts $2 ; 4: 8$ ) ... [and] in Stephen and in the Apostle Paul (e.g., 9:27; 19:8; 28:31)." Ton sees these accounts as a series of cases that illustrate the fulfilment of Jesus' promise given to his witnesses: "When you are arrested, don't worry about how to respond or what to say. God will give you the right words at the right time. For it is not you who will be speaking-it will be the Spirit of your Father speaking through you" (Mt 10:19-20).

\section{Conclusion}

What can we learn about being a 'missional church' from reading the book of Acts with a minority Christian experiencing God's acts in the face of hostility?

- In reading the book of Acts we can learn that God is making people so passionate about Jesus, that they are willing to die for his name and his gospel. This has the potential to rekindle our own love for Jesus.

- In reading the book of Acts we can learn that suffering for Christ, persecution and martyrdom have been the lot of Christ's witnesses from the outset, as modelled and predicted by Jesus. As he was rejected, his followers will equally face rejection because of him. Persecution because of Jesus is not a phenomenon restricted to the Early Church only. We can also learn from fellow Christians nowadays who are facing more suffering for Christ, than we do. From the Book of Acts we can learn that a 'missional church' is likely to face opposition and persecution because of attracting people to Christ which leads them to abandon previous loyalties and unethical

4 He is following Trites 1977:132. 
practices. We need to develop a theological understanding of persecution as resistance to the gospel, which is not narrowed down to physical violence only but also includes ridicule. It will help to define persecution of Christians theologically as "any unjust action of mild to intense levels of hostility directed at Christians resulting in various levels of harm which may not necessarily prevent or limit these Christians' ability to practice their faith or appropriately propagate their faith" (Tieszen 2008:48).

- In reading the book of Acts we can learn the importance of having a full understanding of the sovereignty of God. He reigns, even if the opposite seems to be the case to the human eye. He reigns, whether the political climate is friendly to Christians or not. In his sovereignty he chooses to allow the suffering, persecution and martyrdom of some of his followers and miraculously liberates others from prison and preserves them in order to continue being his witnesses, and he does both in order to glorify his name and to build his kingdom. Our grasp of the sovereignty of God will shape our prayers and reactions to hostility into a manner conforming to Christ. From the Book of Acts we can learn that a 'missional church' should not count on a Constantinian scenario, where the church has the sympathy of those in power, or even has entered into an alliance or symbiosis with those in worldly power. The use of worldly means for advancing church and mission have proven unfruitful and even detrimental in the history of the church. A missional church should start to learn thinking 'pre-Constantinian' again, as it has been originally designed that way.

- In reading the book of Acts we can learn that suffering for Christ is to be considered a privilege and an honour about which we can rejoice. When we see the rejoicing of the believers in Acts in the face of hostility, as well as of contemporary believers, this could have a contagious effect. A reading of the rest of the New Testament and ethical considerations will lead to complementing the readiness to suffer for Christ with active advocacy for the persecuted. ${ }^{5}$

- In reading the book of Acts we can learn to trust the leading and the empowering of the Holy Spirit. With the mandate to be his witnesses (missio dei) God has also equipped us with his power. As reflected in the Book of Acts and taught more explicitly by Jesus and the apostles in other books of the New Testament, God is suffering in and with those he has sent on his mission (compassio dei). He is safeguarding his church 'against the gates of hell' in the midst of hostility and persecution and is enabling it to continue its mission of witnessing to Christ in the midst of suffering and martyrdom. In reading the book of Acts we can learn that a 'missional church' is not primarily driven by ideas, programmes or structures but by the Holy Spirit.

With God's help a 'missional church', also in South Africa, will be able to face the winds of post-Christian ideology and pluralism, not trusting in a position of power or majority, but in the living God who is with his church in mission.

5 Cf. Sauer 2009, Between advocacy and readiness to suffer for Christ. Submitted for publication to Missionalia 2008. 


\section{BIBLIOGRAPHY}

Cunningham, Scott 1997. 'Through many tribulations'. The theology of persecution in Luke-Acts. Sheffield: Sheffield Academic Press.

Lee, Young Kee 1999. God's mission in suffering and martyrdom. PhD Fuller Theological Seminary, SWM.

Penner, Glenn M 2004. In the shadow of the cross: a biblical theology of persecution and discipleship. Bartlesville: Living Sacrifice Books.

Sauer, Christof 2009. Between advocacy and readiness to suffer: Religious liberty and persecution of Christians as topics at the World Evangelical Alliance General Assembly and its Mission Commission Consultation 2008. In: International Journal for Religious Freedom 1(2):73-91. Online: www.iirf.eu.

Tieszen, Charles L 2008. Re-examining religious persecution: constructing a theological framework for understanding persecution. Kempton Park: AcadSA Publishing.

Ton, Josef 2007 [1997]. Suffering, martyrdom and rewards in heaven. Second edition, Oradea: Cartea Crestina.

Trites, Allsion A 1977. The New Testament concept of witness. Cambridge: Cambridge University Press.

Wespetal, Thomas J 2005. Martyrdom and the furtherance of God's plan: The value of dying for the Christian faith. PhD TEDS. 